\title{
The extracellular matrix in breast cancer predicts prognosis through composition, splicing and crosslinking
}

\author{
Claire Robertson
}

\begin{abstract}
The extracellular matrix in the healthy breast has an important tumor suppressive role, whereas the abnormal ECM in tumors can promote aggressiveness, and has been linked to breast cancer relapse, survival and resistance to chemotherapy. This review article gives an overview of the elements of the ECM which have been linked to prognosis of breast cancers, including changes in ECM protein composition, splicing, and microstructure.
\end{abstract}

\section{I: Introduction}

When metastatic breast cancer cells are mixed with murine mammary epithelial cells and injected into the mammary fat pad, one would expect to observe frank tumors [1]. However, instead of tumors, these cancerous cells incorporate into histologically normal ductal structures, respond appropriately to hormones, and even secrete milk proteins [2]. Furthermore, breast epithelial cells with surprisingly abnormal genomes can be found in histologically normal human breast ducts [3-5].

These studies, and many others, show that the correct context can induce non-malignant behavior, whereas, the abnormal environment in tumors can induce progressive genomic instability and tumorigenesis even in non-malignant cells, both in vitro and in animal models [6-8]. Recent work has linked the ECM in tumors to dormancy [9], resistance to chemotherapy or radiation [10-12], metastasis and metastasis tropism [13] again demonstrating the importance of understanding cell-ECM interactions. It has become apparent from both in vitro and clinical work that the ECM signals to cells through both biochemical and physical means with complex interactions between ECM composition, splicing, microstructure, and biomechanics.

This work gives a survey of the alterations to ECM observed in the progression from healthy breast to breast cancer with special attention to biomechanics. We will focus on data from the breast and breast cancer, as cell-matrix interactions have been studied extensively for this organ system and cell culture models of breast development and breast cancer show clear clinical relevance [14, 15].

\section{II: ECM in the healthy breast suppresses tumorigenesis The basement membrane in the normal breast is a tumor suppressor}

The epithelial structures in the breast originate at the nipple, form a branching set of ducts, and end in terminal ductal lobular units, where milk is synthesized. Breast ducts and lobules are bilayered structures: the inner ring of luminal epithelial cells, which secrete milk during lactation, is surrounded by a ring of myoepithelial cells, which are contractile cells with the ability to secrete and organize ECM proteins. Subtending both these layers of cells is a highly specialized layer of extracellular matrix 
proteins termed the basement membrane (BM). Myoepithelial cells are lost with malignant progression [16-18] and are believed to play an important tumor suppressive role in the healthy breast due to their ability to secrete the specialized extracellular matrix proteins of the $\operatorname{BM}[16,19]$. Myoepithelial cells surrounding tumors show a shift in ECM protein secretion, losing expression of tumor-suppressive laminins and increasing expression of collagens $[16,20]$.

The basement membrane (BM), a complex, crosslinked layered structure of multiple laminins, collagen IV and other collagens, proteoglycans including perlecan/heparin sulfate proteoglycan nidogen/entactin, and others. Loss of an intact basement membrane is a key stage in malignant progression with high predictive value for prognosis [21], and animal models show that destruction of the $\mathrm{BM}$ results in genetic instability and tumorigenesis $[7,8]$.The innermost layer of the basement membrane, at the epithelial cell surface, is a network of laminins [22, 23]. In the presence of cell surface ECM receptors, such as dystroglycan, laminin-111 can polymerize into a soft, cohesive network [23, 24], which then induces formation of a more structurally stable collagen IV network subtending the Ln-111 network[25], which epithelial cells do not typically contact. These independent networks are then linked by proteins such as fibronectin and nidogens [26], permitting formation of a cohesive mat of proteins.

Among BM proteins, laminin-111 is absolutely necessary for epithelial specific functions in 3D culture assays, including formation of polarity in human breast epithelial cells [16], and induction of milk protein expression (including beta-casein) in murine mammary gland epithelial cells [27]. Furthermore, tumor reversion, or induction of a quiescent phenotype in malignant cells requires laminin and induction of normal cell-ECM signaling [16, 28]. Laminin-111/Ln-1 has three head domains which can crosslink into a soft cohesive 3D network, whereas other laminin isoforms with truncated head domains, such as laminin-332/Ln-5, laminin-511/Ln-10 or laminin-521/Ln-11, cannot form a network [22, 29], and do not support normal epithelial cell function in vitro, despite the fact that all these isoforms present similar tail domains to cells [16]. Furthermore, some evidence suggests that laminin-332, or collagen IV may support tumor invasion or aggressiveness [30-32].

Both the biomechanics and composition of this laminin network regulate epithelial function: artificially stiffening the laminin network induces epithelial cells to enter an invasive phenotype due to disrupted clustering of $\beta-4$ integrin into hemidesmosomes [33] and increased $\beta 1$ integrin signaling [34, 35]. Increasing the density of laminin sites can overcome increased matrix stiffness [33], showing that cells integrate multiple aspects of ECM.

Given the small dimensions of the breast BM (30-50nm in the human breast [36]), the biomechanical properties of the mammary gland basement membrane itself have never been experimentally determined (though breast stromal tissue has a modulus of 200-400Pa [35, 37]). The BM subtending the retina (which has a similar laminin-rich composition) has a modulus between 1 and 4 $\mathrm{MPa}$, with a difference in matrix biomechanics between its two faces [38], suggesting that despite the thinness of this structure it specializes into sides.

\section{Stroma}


Surrounding the ducts and lobules of the glandular epithelium is the breast stroma, comprised of adipocytes, fibroblasts, and capillaries embedded in a different mix of ECM [39]. The stroma contains blood vessels, adipocytes and fibroblasts embedded in abundant collagen I, chondroitin sulfate and fibronectin [40] (note that the blood vessels have their own laminin-rich BM [41]). Despite their separation by the BM, stroma communicates with epithelia, and stromal changes are observed even in the early stages of malignancy [42]. Stromal ECM plays a major role in tumorigenesis: genetic work from both animal models $[8,43]$ and the clinic $[44,45]$ show that stromal gene expression can alter probablility of developing breast cancer. Importantly, gene expression patterns of normal stroma adjacent to breast cancers shows a different gene expression pattern from normal tissue from unaffected patients [46]. Changes in stromal ECM are observed even in ductal carcinoma in situ (DCIS), where carcinoma cells are confined within an intact basement membrane, including increased deposition of versican [47], loss of decorin [48], and altered expression of Col11A1 [46, 49].

Direct contact between stroma and non-malignant epithelia is not observed except during involution [50]. Breast cancers arising during pregnancy and involution tend to be highly aggressive and metastatic [51], suggesting that the collagen-1 rich stromal ECM, along with inflammatory environment observed in lactation and involution, could be pro-tumorigenic [52]. Supporting this, mouse models of BM destruction or stromal collagen I overexpression, which would tend to increase exposure of epithelia to stromal ECM, show increased tumorigenesis $[8,53]$. Furthermore, non-malignant epithelial cells exposed to increased density of stromal-like collagen I and associated increases in ECM biomechanics undergo transition between formation of normal structures and loss of cell structure and increased growth [35]. The microarchitecture of the fibrilar collagen network (typically collagen I) in the stroma is believed to play a major role in specifying both risk of BC and the stiffness of the stromal ECM [37, 50, $54,55]$, suggesting that stiff stroma could encourage tumor initiation or progression. Depending on species, age and testing method, breast interstitial ECM has been measured to have a modulus of $167 \pm 31 \mathrm{~Pa}$ [35], 0.4kPa [37] and $1.13 \pm 0.78 \mathrm{kPa}$ [55], and the risk of developing $\mathrm{BC}$ has been linked to increases in total breast stiffness both clinically [54].

\section{II: ECM in tumors}

\section{Altered ECM and altered cell response}

In breast cancers, high levels of fibronectin and its splice variants, crosslinked collagen I, and tenascin- $\mathrm{C}$ are associated with poorer survival or time to progression for breast cancer patients, whereas high levels of laminins, high molecular weight hyaluronic acid, heparins, versican, lumican or decorin correlate with better outcomes (summarized in Table 1). While biological mechanisms for some of these links between ECM signatures and prognosis, many open questions remain.

\section{Breast cancer subtypes}

Some of the link between ECM and prognosis may relate to the phenotype or subtypes which associate with certain ECM configurations and the known differences in prognosis associated with these subtypes. Breast cancer is not a single disease [38]: breast cancer prognosis varies with expression of 
key hormone receptors: estrogen receptor (ER), progesterone receptor (PR) and her2/neu/ERbB2 (Her2) [56] histologic grade [57], and presence of metastasis. Recent evidence suggests that the microenvironment in these tumors is different $[58,59]$.

For example, triple negative tumors which display mutant $p 53$, typically have very poor survival [60]. These tumors tend to show complete loss of laminin and high levels of vascularization, which may explain some of the linkage between this form of ECM and poor outcome [61]. Stiff tumors, measured with ultrasound elastography, tend to be the most aggressive types, including triple negative or Her2+ tumors [62]. High levels of hyaluronic acid appears linked to HER2+ cancers, which tend to be more aggressive [61]. Patients with lumican and decorin polymorphisms appear to develop more ER+ cancers [45], which usually have better prognosis.

Similarly, some ECM signatures may only predict prognosis in certain subtypes: for example, SPARC mRNA level, though highest in luminal A tumors, predicts prognosis in basal and Her2+ tumors, but not in luminal types [63], whereas fibronectin, highest in TNBC/basal or Her2+ tumors, has the highest prognostic value in hormone positive cancers [64]. Alternatively, in vitro work has suggested that ECM can alter expression subtype markers, further confounding the link to prognosis $[65,66]$ As a result, studies with different clinical samples can show very different results, and caution is needed in interpreting findings.

\section{ECM protein splicing/ structure changes}

An estimated $75 \%$ of proteins have alternative splice forms [67], and changes to the spliceosome are observed with the progression from normalcy to malignancy $[67,68]$. Unsurprisingly, the ECM proteins with alternative splice forms are often observed to undergo isotype switching during development of cancer, though microenvironmental factors can normalize splicing in malignant cells [69]. The ED-A and ED-B fibronectin splice forms, i.e. the oncofetal splice variants or proangiogenic isoforms [70, 71], display the integrin binding RGD domain differently, [72], and may show different assembly into fibrils [73]. Notably these variants are not found in soluble plasma fibrinogen, suggesting that these forms are more likely to polymerize [74]. Malignant cells express much higher levels of ED-A fibronectin and its receptor, $\alpha 5 \beta 1$ integrin, both of which have been linked to radiation resistance [75]. Likewise, tenascin-c also has multiple alternative splice forms, which are not observed in normal adult breast tissue [76]. In both patient samples and cell culture models, these splice forms have been linked to invasiveness, potentially through MMP-based mechanisms [76, 77].

Furthermore, the abberant ECM in tumors can alter fibronectin splicing even in non-malignant cells, whereas normalization of cell-matrix interactions in malignant cells normalizes fibronectin splicing[75]. Increased tissue stiffness appears to induce global changes in splicing, driving increased expression of ED-B fibronectin [78]. High levels of glucose in media likewise appear to alter expression of ED-B fibronectin splicing along with increasing total levels of fibronectin [79].

\section{Microstructure, biomechanics and crosslinking}


Among ECM components, fibrillar collagen I is believed to be the major determinant of breast and breast cancer stiffness [53], and has been proposed as a link between increased mammographic breast density (a well-known breast cancer risk factor) and increased risk of breast cancer [80]. Mouse models of increased collagen deposition confirm that increased collagen density likewise regulates breast cancer susceptibility [53]. Furthermore, increased expression of fibrillar collagens is observed in invasive breast cancers compared to normal or to DCIS [81, 82] While collagen I is only one of many breast ECM components with cell regulatory effects, it represents the best characterized model for studying microstructure and its effects on cells.

The diverse microarchitectures of fibrillar collagen and the range of resulting biomechanics can result in very different microenvironments despite equivalent levels of collagen [83-85], which potentially explains the weak clinical link between collagen I and prognosis in older studies [86, 87]. It remains difficult to decouple the effects of fiber diameter, pore size and biomechanics, but it appears that all three act on cells (reviewed in [88]). For example, crosslinking and crosslinking density each affect cell invasion, with a significant interaction, such that crosslinking loose ECM environments increased invasiveness, whereas crosslinking dense ECM decreased invasiveness [89].

Due to altered ECM microstructure and crosslinking, the increased stiffness of breast tumors is so different from the surrounding tissue that manual palpation remains an important diagnostic [90]. Tumor stiffness, assessed with ultrasound elastography or atomic force microscopy appears to increase with increasing grade [91] and predicts poorer prognosis [92]. Furthermore, successful chemotherapy decreases tumor stiffness whereas stiffening is observed in chemotherapy-resistant tumors stiffen after treatment [93].

In contrast, softer collagen I rich matrices appear to reduce breast cancer risk and progression. Parity appears to increase collagen I deposition, but in an unorganized, uncrosslinked form, resulting in softer ECM and reduced risk of breast cancers [83]. Collagen III disrupts formation of dense, organized collagen I networks, resulting in softer ECM [94]. Loss of collagen III in mouse models is associated with tumor aggressiveness [94], though Col III is often observed to be overexpressed with increasing tumor grade[20, 81, 82, 95]. Furthermore, reductions in collagen I density via TGF $\beta$ blockade likewise suggest that altering collagen network structure is a potential therapeutic target [96].

A dense network of collagen fibers perpendicular to tumor border predicts invasiveness and poorer overall survival $[97,98]$. In mesenchymal cells, organization of fibriliar matrices is the major determinant of migration patterns, such that cell migration persistence tends to be highest in aligned matrices [97, 99-101]. Both non-malignant and malignant epithelial cells respond to the biomechanics of their surrounding matrix [35], through multiple mechanisms [6, 33, 35, 102]. Lysyl oxidases, by crosslinking collagens increase tumor stiffness [103], and predict prognosis [86].

\section{ECM and chemotherapy}

Resistance to chemotherapy has been linked to features of ECM through several avenues. In ERbreast cancers, gene expression patterns typical of reactive stroma predicted resistance to chemotherapy, though no link was found between this signature and outcome in untreated patients 
[10]. Similarly, tumor stiffness measured with ultrasound elastography predicted residual tumor burden after chemotherapy [104-106]. Interestingly, clinical response to chemotherapy involved a softening of the tumor site, whereas resistant tumors became stiffer after treatment [93]. Among elements of reactive stroma, increased ECM stiffness predicted resistance in vitro to the broad spectrum tyrosine kinase inhibitor sorafenib [107].

Integrins and many of the tyrosine kinase receptors (such as EGFR [108], ErbB2, VEGFRs, HFGRs etc.) are known to cross regulate each other in stiff environments, potentiating both integrin signaling and often increasing receptor potency [107, 109-111]. Her2 is acutely regulated by FAK, such that ECM stiffening is a powerful regulator of Her2 and of Her2 resistance [65, 110, 112]. Adhesion to laminin-332 through a6b4 has also been linked to trastuzumab resistance through the transmembrane protein CD151 [113]. We would argue that further work is urgently needed to understand the role of ECM in mediating chemotherapy resistance.

\section{III: Conclusions how does ECM remodeling keep healthy tissues healthy and how did tumors get that way?}

The natural history of breast cancer still remains poorly understood, and may differ by cell of origin $[114,115]$, subtype or yet unknown factors. However, a preponderance of evidence now shows that the insoluble proteins comprising the extracellular matrix (ECM) can suppress tumor development and progression, whereas the abnormal ECM in tumors can promote progression of cancers and resistance to treatment. The diverse mechanisms by which cells sense and respond to their surrounding ECM represent an attractive target for new therapeutics for cancers [116]. However, the dramatic failure in clinical trials of one such class of treatment, namely MMP inhibitors [117] highlights the need for improved models and improved understanding of cell-ECM interactions. Many open questions remain about the complex interactions between ECM proteins, microstructure and biomechanics. 
Table 1: Clinical studies linking ECM to breast cancer progression survival

\begin{tabular}{|c|c|c|c|}
\hline Methods & Patient cohort & Results & Ref \\
\hline \multicolumn{4}{|l|}{ Transcriptomic } \\
\hline $\begin{array}{l}\text { RNA microarray for } \\
\text { genes which predict } \\
\text { metastasis }\end{array}$ & $\begin{array}{l}98 \mathrm{BC} \\
\text { All under } 55 \text { yrs. }\end{array}$ & $\begin{array}{l}231 \text { genes were linked to prognosis including ColIVa2, } \\
\text { MMP9 }\end{array}$ & [118] \\
\hline $\begin{array}{l}\text { RNA microarray to } \\
\text { distinguish between } \\
\text { lobular and ductal } \\
\text { cancers }\end{array}$ & $\begin{array}{l}106 \text { IDC, } 17 \text { ILC, } 6 \\
\text { normal }\end{array}$ & $\begin{array}{l}\text { Among } 11 \text { genes differentially expressed between ductal } \\
\text { and lobular cancers, Osteopontin/SPP1, expressed more } \\
\text { in ductal tumors than lobular, Elastin, TSP1 observed in } \\
\text { lobular but not ductal }\end{array}$ & [119] \\
\hline $\begin{array}{l}\text { mRNA-Seq to } \\
\text { determine genes } \\
\text { differentially } \\
\text { expressed between } \\
\text { DCIS and IDC and } \\
\text { between normal } \\
\text { and DCIS }\end{array}$ & $\begin{array}{l}4 \text { normal, } 7 \text { DCIS, } \\
12 \text { IDC }\end{array}$ & $\begin{array}{l}\text { Normal to DCIS did not show changes in ECM genes } \\
\text { Between DCIS and IDC, 13\% of differentially expressed } \\
\text { genes classified as ECM } \\
\text { Among } 8 \text { top genes differently expressed between DCIS } \\
\text { and IDC, } 7 \text { were ECM related: COL1A1, SPARC, COL1A2, } \\
\text { COL6A1, Lumican, COL3A1, FN1 }\end{array}$ & [95] \\
\hline $\begin{array}{l}\text { mRNA seq of MEP } \\
\text { isolated by CD10 } \\
\text { MACS, LEP, stroma } \\
\text { and immune cells }\end{array}$ & $\begin{array}{l}2 \text { Normal, } 2 \text { DCIS } \\
12 \text { IDC, }\end{array}$ & $\begin{array}{l}\text { Most consistent and dramatic gene changes from normal } \\
\text { to DCIS to IDC were found in MEP } \\
\text { Top } 20 \text { differentially expressed in DCIS MEP vs. Normal } \\
\text { include: Col1A1, Col3A1, Col6A2, Thbs2, Timp3, CTSF, } \\
\text { Decorin, biglycan }\end{array}$ & {$[20]$} \\
\hline $\begin{array}{l}\text { Microarray of } \\
\text { unsorted tumor } \\
\text { tissue for ECM } \\
\text { related genes } \\
\text { followed by } \\
\text { unbiased clustering } \\
\text { into } 4 \text { groups. Use } \\
\text { of these gene } \\
\text { signatures to predict } \\
\text { outcome }\end{array}$ & $\begin{array}{l}114 \text { early stage } \\
\text { BC } \\
59 \text { NODE+ } \\
74 \text { Hormone } \\
\text { Receptor+ } \\
98 \text { Tumor } \\
\text { size }>2 \mathrm{~cm}\end{array}$ & $\begin{array}{l}\text { ECM1: Hi in MARCO, ITGAs, PCAM, VECAM, MMP9, } \\
\text { ECM2: Hi in PUNC, COL7A1 } \\
\text { ECM3: Hi SPARC, FBLNs, COLs } \\
\text { ECM4: Hi ADAMs, SERPINAs } \\
\text { ECM1: Decreased survival or distant disease free survival, } \\
\text { in all samples or luminal type cancers. } \\
\text { PUNC and SPARC down and MARCO up: decreased } \\
\text { survival } \\
\text { ECM2: tumors were characterized by a more } \\
\text { heterogeneous expression of ECM-related genes. Most }\end{array}$ & {$[61]$} \\
\hline
\end{tabular}




\begin{tabular}{|c|c|c|c|}
\hline & 44 Grade III & $\begin{array}{l}\text { likely to be luminal B, or Her2+ } \\
\text { ECM3 tumors showed mainly up-regulation of genes } \\
\text { encoding macromolecules involved in the maintenance } \\
\text { of connective tissue; in particular, collagens, laminins, } \\
\text { fibrillins, and the matrix-associated proteins. No change } \\
\text { in overall survival, but predicted poorer outcome in } \\
\text { luminal cancers } \\
\text { ECM4: had a favourable outcome and was defined by the } \\
\text { overexpression of a set of protease inhibitors belonging } \\
\text { to the serpin family }\end{array}$ & \\
\hline $\begin{array}{l}\text { RNA-seq of serum } \\
\text { stimulated } \\
\text { fibroblasts to } \\
\text { determine a wound } \\
\text { response gene } \\
\text { siguature followed } \\
\text { by RNAseq in BC } \\
\text { samples }\end{array}$ & $\begin{array}{l}295 \text { BC } \\
10 \text { Node neg. } \\
120 \text { Node pos. }\end{array}$ & $\begin{array}{l}\text { Increased expression of genes induced by serum predict } \\
\text { higher metastasis and lower survival }\end{array}$ & [120] \\
\hline $\begin{array}{l}\text { mRNA seq of } \\
\text { matched laser } \\
\text { capture } \\
\text { microdissected } \\
\text { tumor epithelia, } \\
\text { tumor stroma, } \\
\text { adjacent epithelia } \\
\text { and adjacent normal }\end{array}$ & $\begin{array}{l}14 \text { IDC } \\
14 \text { grade } 1-3 \text { IDC, } \\
11 \text { Er+, } 5 \text { Her2+, } \\
10 \text { node positive }\end{array}$ & $\begin{array}{l}\text { Tumor stroma massively overexpressed ECM and ECM } \\
\text { remodeling genes } \\
\text { Enriched in stroma compared to tumor include: } 200 \\
\text { ECM components, } 23 \text { collagens, } 26 \text { MMPs, } \\
\text { Top } 50 \text { enriched in IDC compared to DCIS include: } \\
\text { MMP11, MMP2, MMP14, }\end{array}$ & [121] \\
\hline $\begin{array}{l}\text { mRNA microarray } \\
\text { for genes which } \\
\text { predict lung } \\
\text { metastasis tropism }\end{array}$ & $82 \mathrm{BC}$ & $\begin{array}{l}54 \text { gene signature predicted lung metastasis in all } \\
\text { patients, ER- patients and poor prognosis patients, but } \\
\text { did not predict bone metastasis } \\
\text { Among } 54 \text { genes predicting lung tropism: COL6A1, MMP1 } \\
\text { TNC, MMP2, SPARC }\end{array}$ & [13] \\
\hline $\begin{array}{l}\text { Previously published } \\
\text { datasets were } \\
\text { analysed for gene } \\
\text { expression patterns } \\
\text { in ER-BC }\end{array}$ & $\begin{array}{l}186 \text { ER- and } 527 \\
E R+B C\end{array}$ & $\begin{array}{l}\text { ECM enriched cluster had medium prognosis } \\
7 \text { gene signature in ER- cancers: High in and low in } \\
\text { SPP1/Osteonectin predicted higher rate of death or } \\
\text { distant metastasis (HR 2) }\end{array}$ & [59] \\
\hline
\end{tabular}




\begin{tabular}{|c|c|c|c|}
\hline $\begin{array}{l}\text { Analysis of genes } \\
\text { predictive of } \\
\text { tamoxifen } \\
\text { resistance in ER+ } \\
\text { tumors }\end{array}$ & $\begin{array}{l}112 \text { ER+ primary } \\
B C\end{array}$ & $\begin{array}{l}\text { Among } 81 \text { gene signature predictive of tamoxifen } \\
\text { resistance: TIMP3, FN1, LOX, Col1A!, SPARC, TNC }\end{array}$ & [122] \\
\hline $\begin{array}{l}\text { PCR for COL1A1, } \\
\text { FN1, LOX, SPARC, } \\
\text { TIMP3, and TNC }\end{array}$ & $\begin{array}{l}1286 \text { primary BC } \\
680 \text { Node neg. } \\
73.3 \% \text { ER+ }\end{array}$ & $\begin{array}{l}\text { All } 6 \text { ECM genes were correlated with each other } \\
\text { FN, LOX, SPARC all were correlated with poorer survival } \\
\text { Col1A1 hi: better histologic grade, smaller tumors, ErbB2 } \\
\text { positive and EGFR hi } \\
\text { FN1 hi: Small tumors, more lymph node involvement, } \\
\text { ErbB2 positive and EGFR hi } \\
\text { LOX hi: More }\end{array}$ & [86] \\
\hline $\begin{array}{l}\text { RNA seq in } \\
\text { previously published } \\
\text { dataset, along with } \\
\text { array for differences } \\
\text { between normal } \\
\text { and BC }\end{array}$ & $\begin{array}{l}24 \text { IBC, } 38 \\
\text { ipsilateral normal, } \\
3 \text { contralateral } \\
\text { normal, } 28 \\
\text { normal }\end{array}$ & $\begin{array}{l}46 \text { genes which distinguish normal from BC } \\
\text { Cancers compared to normal include: Up: Col1A1, } \\
\text { Col1A2, Col3A1, Col5A1, Col5A2, Col6A3, Col8A1, MMP 1, } \\
\text { 10, 11, 12, } 13 \text { Down: CD44, MMP2, } \\
\text { Luminal/Lobular include: CTGF, MMP2, AR, CFB, CD44, } \\
\text { CDKN1B, ETAA1, FGFR2, TNFRSR10B } \\
\text { Basal tumor specific include: MMP10, MMP12, } \\
\text { SPP1/osteopontin, }\end{array}$ & [81] \\
\hline $\begin{array}{l}\text { nRNA seq of genes } \\
\text { differentially } \\
\text { expressed between } \\
\text { DCIS and IBC }\end{array}$ & $\begin{array}{l}126 \text { DCIS and IDC } \\
\text { along with } \\
\text { analysis of } \\
\text { previously } \\
\text { published work }\end{array}$ & $\begin{array}{l}\text { Top } 25 \text { genes overexpressed in IDC compared to DCIS } \\
\text { include: Col1A2, MMP11, Col11A1, Thbs2, Col6A3, } \\
\text { POSTN, Col3A1, SPARC, Col5A2, Col8A1, Lumican, FN, } \\
\text { Col5A1, } \\
\text { Most differentially expressed gene classes: ECM and ECM } \\
\text { organization }\end{array}$ & $\begin{array}{l}{[82]} \\
{[82]}\end{array}$ \\
\hline $\begin{array}{l}\text { Microdissection of } \\
\text { stroma and } \\
\text { epithelial } \\
\text { compartments for } \\
\text { matched adjacent } \\
\text { normal, DCIS and } \\
\text { IDC, followed by } \\
\text { whole genome } \\
\text { sequencing }\end{array}$ & $\begin{array}{l}17 \text { matched IDC } \\
\text { and DCIS, } \\
\text { Of which, } 13 \text { ER+, } \\
3 \text { Her2+, } 3 \text { TNBC }\end{array}$ & $\begin{array}{l}\text { Different between DCIS and IDC epithelia: . COL17A, } \\
\text { COL5A2, COL22A1, COL8A1, COL12A1, COL10A1, } \\
\text { COL11A1, MMP13, GPC6, KLK5, FREM1 } \\
\text { Different between DCIS and IDC in both epithelia and } \\
\text { stroma: COL11A1 } \\
\text { Adjacent normal and normal tissue from unaffected } \\
\text { patients do not cluster }\end{array}$ & [46] \\
\hline $\begin{array}{l}\text { RNA microarray to } \\
\text { distinguish matched } \\
\text { DCIS and IDC in }\end{array}$ & $\begin{array}{l}20 \text { matched DCIS } \\
\text { and IDC }+ \\
\text { (unmatched) } 7\end{array}$ & $\begin{array}{l}\text { Among genes } 56 \text { upregulated in IDC vs. DCIS: COL11A1, } \\
\text { COL10A1, FN1, COL12A1, MMP13, THBS2, SPARC, } \\
\text { LRRC15, ASPN, and MMP11, and MMP14 }\end{array}$ & [123] \\
\hline
\end{tabular}




\begin{tabular}{|c|c|c|c|}
\hline concurrent cases & DCIS, 8 normal & & \\
\hline \multicolumn{4}{|l|}{ Multiple targets } \\
\hline $\begin{array}{l}\text { Laser capture } \\
\text { microdissection of } \\
\text { epithelial cells and } \\
\text { LC/ mass spec for } \\
\text { proteins } \\
\text { differentially } \\
\text { expressed between } \\
\text { normal epithelia and } \\
\text { ER+BC }\end{array}$ & $\begin{array}{l}9 \text { normal and } 9 \\
\text { ER+PR+ IBC: } \\
8 \text { IDC, } 1 \text { ILC, } \\
\text { grades 1-3, } 1 \\
\text { Her2+ }\end{array}$ & $\begin{array}{l}\text { Among } 1623 \text { differentially expressed proteins } \\
\text { Overexpressed in normal: LamA3, LamB2, LamC1, } \\
\text { Col1A1, fibrinogen A }\end{array}$ & [124] \\
\hline $\begin{array}{l}\text { HC for TN, CD, Coll, } \\
\text { LN,FN, CD44s and } \\
\text { Ki- } 67 \text { and } \\
\text { correlation with } \\
\text { survival }\end{array}$ & $138 \mathrm{BC}$ & $\begin{array}{l}\text { Survival analysis showed an increased mortality risk } \\
\text { associated with high levels of TN expression } \\
\text { TN expression in the tumour stroma was positively } \\
\text { correlated with tumour grade and size, CD44s } \\
\text { expression, tumour and stromal CD expression as well as } \\
\text { with FN, laminin and Coll expression in the same areas. } \\
\text { Among the ECM proteins, only TN expression was } \\
\text { independently correlated with patients' survival. }\end{array}$ & [87] \\
\hline $\begin{array}{l}\text { IHC for TN, versican, } \\
\text { CS, HA and } \\
\text { correlation with } \\
\text { survival and relapse }\end{array}$ & $\begin{array}{l}86 \text { node negative } \\
\text { IDC, } 54 \mathrm{ER}+\end{array}$ & $\begin{array}{l}\text { Versican correlated with CS, TN correlated with HA in } \\
\text { stroma. } \\
\text { High TN tend to be high grade, large tumors, } \\
\text { HA high tended to be low grade tumors } \\
\text { Versican predicted relapse free survival }\end{array}$ & [125] \\
\hline \multicolumn{4}{|l|}{ Laminins } \\
\hline $\begin{array}{l}\mathrm{IHC} \text { and } \mathrm{ISH} \text { for } \mathrm{LN} \\
\mathrm{A} 5, \mathrm{~B} 1 \text { and } \mathrm{B} 2 \text { chains }\end{array}$ & $\begin{array}{l}3 \text { normal, } \\
18 \text { IDC, grade } 2 \text { or } \\
3 \text {, and } 3 \\
\text { metastases }\end{array}$ & $\begin{array}{l}\text { LN A5 observed in vascular tissue and BM of all epithelia } \\
\text { LN A5 observed in cytoplasm of all tumors } \\
\text { LNB1 and B2 observed in IDC only }\end{array}$ & [126] \\
\hline
\end{tabular}




\begin{tabular}{|c|c|c|c|}
\hline $\begin{array}{l}\text { PCR for LAMA3, } \\
\text { LAMC2 and others } \\
\text { in the tumor, } \\
\text { invasive front and } \\
\text { adjacent normal }\end{array}$ & 4 DCIS and 7 IDC & $\begin{array}{l}\text { LAMA3 and LAMC2, and ITGA6 and ITGB4 overexpressed } \\
\text { in invasive zone compared to main tumor or adjacent } \\
\text { normal, but not LAMA2, LAMB1, LAMC1 or SPARC }\end{array}$ & {$[30]$} \\
\hline $\begin{array}{l}\text { IHC for LAMB3 in } \\
\text { cytoplasm of } \\
\text { epithelia and } \\
\text { comparison } \\
\text { between TNBC and } \\
\text { non-TNBC }\end{array}$ & $243 \mathrm{BC}, 80 \mathrm{TNBC}$ & $\begin{array}{l}\text { LAMB3 staining in cytoplasm observed in } 70 \% \text { of TNBC } \\
\text { and only } 15 \% \text { of non-TNBC }\end{array}$ & [127] \\
\hline $\begin{array}{l}\text { IHC for human } \\
\text { laminin }\end{array}$ & $\begin{array}{l}18 \\
\text { fibroadenomas } \\
22 \text { cases of } \\
\text { fibrocystic } \\
\text { disease, } 96 \text { IDC } \\
\text { and } 26 \text { DCIS }\end{array}$ & $\begin{array}{l}\text { Continuous staining for laminin observed in benign } \\
\text { samples, 77\% of DCIS showed continuous laminin } \\
\text { staining and disrupted laminin staining observed in IDC. } \\
\text { Small-sized tumours, those without lymphatic invasion } \\
\text { and lymph node-negative tumours showed more } \\
\text { complete patterns of laminin expression }\end{array}$ & [128] \\
\hline $\begin{array}{l}\text { IHC for LAMB3 } \\
\text { LAMC2 }\end{array}$ & $\begin{array}{l}25 \text { BC patients } 7 \\
\text { squamous, } 4 \\
\text { sarcomatous, } 8 \\
\text { chondroid, } 1 \\
\text { fibromatosislike } \\
\text { metaplastic } \\
\text { carcinomas, and } 5 \\
\text { cases with } 2 \\
\text { metaplastic } \\
\text { components }\end{array}$ & $\begin{array}{l}\text { Both LAMB3 and LAMC2 observed in } 96 \% \text { of tumors. All } \\
\text { ER- or TNBC expressed LAMB3 and LAMC2 where only } \\
15 \% \text { of high grade tumors expressed LAMB3 or LAMC2 }\end{array}$ & [129] \\
\hline IHC for laminin 5 & 55 patients & $\begin{array}{l}\text { FGF-2 and laminin } 5 \text { expression were found throughout } \\
\text { benign and atypical dedifferentiation in mammary tissue } \\
\text { samples and were lost primarily with transformation to } \\
\text { invasive cancer. }\end{array}$ & [130] \\
\hline \multicolumn{4}{|l|}{ Fibronectin } \\
\hline $\begin{array}{l}\text { ISH for total FN, ED- } \\
\text { A and ED-B } \\
\text { fibronectins. }\end{array}$ & $\begin{array}{l}36 \text { IDC and } 13 \\
\text { benign lesions }\end{array}$ & $\begin{array}{l}\text { FN and ED-A and ED-B expression observed in tumors, } \\
\text { almost absent in benign lesions }\end{array}$ & [131] \\
\hline $\begin{array}{l}\text { IHC for } \beta 1 \text { integrin, } \\
\text { fibronectin and }\end{array}$ & 249 IBC & $\begin{array}{l}\text { HR for increased grade: } \beta 1 \text { integrin } 1.43, \mathrm{FN} \text { staining: } \\
1.03 \text {, Ln-111 staining } 0.95\end{array}$ & {$[132$} \\
\hline
\end{tabular}




\begin{tabular}{|c|c|c|c|}
\hline laminin-111 & & & \\
\hline $\begin{array}{l}\text { IHC for FN in } \\
\text { epithelia (E-FN) and } \\
\text { stroma (S-FN) }\end{array}$ & $\begin{array}{l}1596 \text { invasive } \\
\text { breast cancer } \\
\text { samples }\end{array}$ & $\begin{array}{l}\text { Epithelial FN associated with increased tumor grade and } \\
\text { lymph node positivity, ER/PR- and Her2+ and worse } \\
\text { overall survival and disease free progression. } \\
\text { E-FN predicted survival especially in ER/PR+ group } \\
\text { S-FN did not predict survival }\end{array}$ & [64] \\
\hline \multicolumn{4}{|l|}{ Collagens } \\
\hline $\begin{array}{l}\text { MPM for aligned } \\
\text { fibrillar collagens } \\
\text { and correlation with } \\
\text { prognosis }\end{array}$ & 196 samples & $\begin{array}{l}\text { Aligned collagen predicted poor survival, with a HR } \\
\text { between } 3.0 \text { and } 3.9 \text {, independently of tumor grade, } \\
\text { nodal status or size, or ER, PR or HER2 status }\end{array}$ & [98] \\
\hline $\begin{array}{l}\text { Microarray for prolyl } \\
4 \text { hydroxylase } 1 \text { and } \\
2\end{array}$ & TCGA dataset & $\begin{array}{l}\text { Higher prolyl } 4 \text { hydroxylase } 1 \text { and } 2 \text { in cancer compared to } \\
\text { adjacent, higher expression of either }=>\text { decreased } \\
\text { patient survival }\end{array}$ & [133] \\
\hline $\begin{array}{l}\text { Microarray for Prolyl } \\
4 \text { hydroxylase } 2 \text {, and } \\
\text { Col1A1, Col3A1, and } \\
\text { Col4A1 }\end{array}$ & $\begin{array}{l}\text { Previously } \\
\text { published } \\
\text { datasets }\end{array}$ & $\begin{array}{l}\text { P4HA2 tends to be higher with increasing grade, higher in } \\
\text { IDC than ILC, higher in ERBB2+ cancers, and P4H2 high } \\
\text { predicts worse survival in all, ER+ and ER- cancers (HR } \\
\text { 1.4) }\end{array}$ & [134] \\
\hline $\begin{array}{l}\text { Microarray for Prolyl } \\
4 \text { hydroxylase } 2 \text { and } \\
\text { Col1A1, Col2A1 and } \\
\text { Col4A1 }\end{array}$ & $\begin{array}{l}\text { Large microarray } \\
\text { dataset ( } 2000 \\
\text { IBC and IDBC) }\end{array}$ & $\begin{array}{l}\text { Higher expression of } \mathrm{P} 4 \mathrm{H} 2 \text { correlated with higher } \\
\text { collagen expression, higher clinical stage, Her2 positivity. } \\
\text { Higher P4H2 expression predicted worse survival in all, } \\
\text { ER+ and ER- populations }\end{array}$ & [135] \\
\hline $\begin{array}{l}\text { LS- MS for type XIV } \\
\text { collagen }\end{array}$ & $\begin{array}{l}20 \text { patients half } \\
\text { with multiple } \\
\mathrm{LN}+\text {, half with } \mathrm{LN}-\end{array}$ & $\begin{array}{l}\text { type XIV collagen expression was predictive of lymph } \\
\text { node metastasis along with type I collagen, } \\
\text { MSTP161/proline/arginine-rich end leucine-rich repeat } \\
\text { protein (PRELP) or prolargin, angiomotin and hexokinase } \\
\text { type I }\end{array}$ & [136] \\
\hline IHC for Col11A1 & $\begin{array}{l}201 \text { core needle } \\
\text { biopsies, } 87 \text { IDC, } \\
14 \text { ILC, } 19 \text { DCIS, } 6 \\
\text { LCIS, } 30 \\
\text { fibroadenoma, }\end{array}$ & $\begin{array}{l}\text { Higher Col11A1 observed near tumor expansion areas. } \\
\text { High Col11A1 predicted infiltration (sensitivity .93, } \\
\text { specificity .97) }\end{array}$ & [49] \\
\hline \multicolumn{4}{|l|}{ Tenascin } \\
\hline IF for tenascin-C and & $39 \mathrm{BC}$ & High Tenascin predicted shorter lung metastasis free & [137] \\
\hline
\end{tabular}




\begin{tabular}{|c|c|c|c|}
\hline $\begin{array}{l}\text { correlation with } \\
\text { lung metastatic } \\
\text { potential }\end{array}$ & & survival & \\
\hline $\begin{array}{l}\text { IHC, ISH for all TN, } \\
\text { truncated TN, TN } \\
\text { extra exon } 16 \text { and } \\
\text { TN extra exons } 14- \\
16\end{array}$ & $\begin{array}{l}15 \text { benign } 5 \\
\text { fibroadenomas } \\
13 \text { DCIS, and } 35 \\
\text { carcinomas ( } 10 \\
\text { grade I, } 9 \text { grade II, } \\
\text { and } 9 \text { grade III) }\end{array}$ & $\begin{array}{l}\text { Although all tissues expressed the fully truncated TN, } \\
\text { exon } 16 \text { (TN16) and exons } 14 \text { and } 16 \text { (TN14/16), } \\
\text { associated with invasive phenotype }\end{array}$ & [76] \\
\hline $\begin{array}{l}\text { rtPCR for TNC and } \\
\text { TN additional } \\
\text { domain } 1 \text { and } \\
\text { additional domain } 2 \\
\text { isoforms }\end{array}$ & $\begin{array}{l}155 \text { IDC, } 62 \text { IDC, } \\
25 \text { ILC, } 14 \text { benign, } \\
33 \text { normal } 68>40 \\
\text { yrs, } 62 \text { idc }<40 \text { YR, } \\
25 \text { ILC }<40 y r\end{array}$ & $\begin{array}{l}\text { Extra domain TNCs observed more often in younger } \\
\text { women, and AD1 associated with ER- and high grade } \\
\text { tumors. }\end{array}$ & [138] \\
\hline \multicolumn{4}{|l|}{$\begin{array}{l}\text { Hyaluronic Acid, } \\
\text { heparin and } \\
\text { versican }\end{array}$} \\
\hline IHC for syndecan-1 & $\begin{array}{l}63 \text { triple positive } \\
\text { IDC and } 61 \\
\text { matched adjacent } \\
\text { normal }\end{array}$ & $\begin{array}{l}\text { Triple positive IDC tended to express high syndecan-1. } \\
\text { High syndecan-1 predicted low invasiveness and low } \\
\text { grade }\end{array}$ & [139] \\
\hline IHC for syndecan-1 & $\begin{array}{l}72 \text { patients, } \\
\text { mostly DC, grade } \\
\text { ii-iii, }\end{array}$ & $\begin{array}{l}\text { Syndecan-1 medium tumors tended to be ER+. Syndecan } \\
\text { high tended to be ER-. High levels of syndecan-1 in } \\
\text { epithelia predict poor survival }\end{array}$ & [140] \\
\hline $\begin{array}{l}\text { IS for Versican, } \\
C S, T N, H A\end{array}$ & $\begin{array}{l}86 \text { patients with } \\
\text { node negative } B C\end{array}$ & $\begin{array}{l}\text { High versican predicted shorter relapse free survival. } \\
\text { Versican high tumors tended to be ER+ and PR+ Tenascin } \\
\text { high samples tended to be larger and higher grade, HA in } \\
\text { stroma predicted higher grade, HA in cancer cells } \\
\text { predicted higher grade. }\end{array}$ & [125] \\
\hline IHC for versican & $\begin{array}{l}9 \text { LCIS, mixed, and } \\
28 \mathrm{DCIS}\end{array}$ & $\begin{array}{l}\text { versican is strongly expressed in the stroma of some } \\
\text { DCIS, and versican stromal staining predicts high grade } \\
\text { category and comedo pattern }\end{array}$ & [47] \\
\hline IHC for Versican & $\begin{array}{l}58 \text { node negative } \\
\text { BC }\end{array}$ & Decreased relapse free survival (HR 6.35) & [41] \\
\hline IHC for HA & 143 primary, & HA positive cells correlated with lymph node positivity, & [141] \\
\hline
\end{tabular}




\begin{tabular}{|c|c|c|c|}
\hline & $\begin{array}{l}\text { invasive BC 91\% } \\
\text { ER+ }\end{array}$ & $\begin{array}{l}\text { low grade, more likely to be ER and PR negative, } \\
\text { decreased survival }\end{array}$ & \\
\hline $\begin{array}{l}\text { IHC for HA and CD44 } \\
\text { (HA receptor) }\end{array}$ & $\begin{array}{l}156 \text { IBC, } 89 \text { HER2- } \\
\text {, } 67 \text { HER2+ }\end{array}$ & $\begin{array}{l}\text { High HA more likely to be seen in HER2 positive cases, } \\
\text { High HA correlates with larger tumor size, lymph node } \\
\text { positivity, ER-, PR- and poor differentiation }\end{array}$ & [142] \\
\hline $\begin{array}{l}\text { WB for lumican, } \\
\text { decorin, ER and PR }\end{array}$ & $\begin{array}{l}140 \text { node } \\
\text { negative IBC }\end{array}$ & $\begin{array}{l}\text { Low lumican associated with low ER and PR, and larger } \\
\text { tumor size. Low Lumican and decorin both associated } \\
\text { with with poorer survival } \\
\text { Recurrence free survival HR: ER 6.1, PR 4.02, decorin } \\
2.25 \text {, } \\
\text { Overall survival HR: PR } 12.28 \text {, ER } 2.86 \text {, decorin } 3.39\end{array}$ & [143] \\
\hline $\begin{array}{l}\text { WB for lumican, } \\
\text { decorin and PCR for } \\
\text { lumican and decorin } \\
\text { mRNA }\end{array}$ & $15 \mathrm{BC}$ & $\begin{array}{l}\text { lumican was highly abundant relative to decorin, while } \\
\text { biglycan and fibromodulin are only detected occasionally } \\
\text { lumican mRNA was increased in tumours while decorin } \\
\text { mRNA was decreased } \\
\text { in neoplastic relative to adjacent normal stroma along } \\
\text { with an increase in lumican, but not decorin. }\end{array}$ & [144] \\
\hline IHC for decorin & $\begin{array}{l}98 \text { samples IBC } \\
\text { and } 22 \text { were from } \\
\text { patients with } \\
\text { DCIS }\end{array}$ & $\begin{array}{l}\text { Decorin was observed in stroma but not epithelia. } \\
\text { Average decorin expression decreased from normal to } \\
\text { DCIS to IDC }\end{array}$ & [48] \\
\hline $\begin{array}{l}\text { IHC for Syndecan } \\
1,4, \text { and Glypican } 1\end{array}$ & 207 BC & $\begin{array}{l}\text { Glypican-1 detected in a small sample of BC } \\
\text { Higher level of Syndecan } 1 \text { and }-4 \text { predicted higher size, } \\
\text { grad, Ki67 and Er- status. Syndecan } 1 \text { hi also predicted } \\
\text { lymph node positivity and worse survival }\end{array}$ & [145] \\
\hline $\begin{array}{l}\text { Northern blot for } \\
\text { glypican } 1,2,3,4 \\
\text { and syndecan }-1\end{array}$ & $\begin{array}{l}20 \text { BC with } \\
\text { adjacent normal } \\
\text { control, mostly } \\
\text { stage } 1 .\end{array}$ & $\begin{array}{l}\text { Increased Glypican-1, } 3 \text { and Syndecan-1 expression in } \\
\text { cancers relative to adjacent normal }\end{array}$ & [146] \\
\hline $\begin{array}{l}\text { IHC for Heparanase- } \\
1\end{array}$ & $\begin{array}{l}80 \text { normal to } \\
\text { metastatic } B C \\
\text { samples }\end{array}$ & $\begin{array}{l}\text { Heparanase-1 expression correlates with worse clinical } \\
\text { grade }\end{array}$ & [147] \\
\hline $\begin{array}{l}\text { IHC for Heparanase } \\
\text { and COX2 }\end{array}$ & $\begin{array}{l}246 \text { breast tumor } \\
\text { samples }\end{array}$ & $\begin{array}{l}\text { overexpression of HPA and COX-2 was associated with } \\
\text { increased likelihood of lymph node positivity in large, } \\
\text { high-grade tumors }\end{array}$ & [148] \\
\hline SPARC/ & & & \\
\hline
\end{tabular}




\begin{tabular}{|l|l|l|l|}
\hline OSTEONECTIN & & & \\
\hline $\begin{array}{l}\text { Microarray for 7 } \\
\text { genes which } \\
\text { correlate with } \\
\text { SPARC }\end{array}$ & $\begin{array}{l}\text { 1729 systemically } \\
\text { untreated } \\
\text { patients from } \\
\text { previously } \\
\text { published } \\
\text { datasets }\end{array}$ & $\begin{array}{l}\text { SPARC tends to be highest in luminal-A type, followed by } \\
\text { luminal-B followed by basal. } \\
\text { High SPARC predicts worse survival in HER2+, and basal } \\
\text { cancers }\end{array}$ & [63] \\
\hline
\end{tabular}

\section{Acknowledgements}

Thanks to Mina Bissell for her continued mentorship and support. Thanks to Amir Jaberi, Rosalyn Sayaman, Elizabeth Yu for assistance with literature search and editing. This work was supported by DOD Breast cancer research program (BC133875) and the L'Oreal for women in science program

\section{References}

1. Cailleau, R., M. Olivé, and Q.J. Cruciger, Long-term human breast carcinoma cell lines of metastatic origin: Preliminary characterization. In Vitro, 1978. 14(11): p. 911-915.

2. Bussard, K.M. and G.H. Smith, Human Breast Cancer Cells Are Redirected to Mammary Epithelial Cells upon Interaction with the Regenerating Mammary Gland Microenvironment In-Vivo. PLoS ONE, 2012. 7(11): p. e49221.

3. Larson, P.S., et al., Loss of Heterozygosity or Allele Imbalance in Histologically Normal Breast Epithelium Is Distinct from Loss of Heterozygosity or Allele Imbalance in Co-Existing Carcinomas. Am J Pathol, 2002. 161(1): p. 283-290.

4. Ellsworth, D., et al., Genomic patterns of allelic imbalance in disease free tissue adjacent to primary breast carcinomas. Breast Cancer Research and Treatment, 2004. 88(2): p. 131-139.

5. Lakhani, S.R., et al., Genetic alterations in 'normal' luminal and myoepithelial cells of the breast. The Journal of Pathology, 1999. 189(4): p. 496-503.

6. Provenzano, P.P., et al., Matrix density-induced mechanoregulation of breast cell phenotype, signaling, and gene expression through a FAK-ERK linkage. Oncogene, 2009. 28(49): p. 43264343.

7. Radisky, D.C., et al., Rac1b and reactive oxygen species mediate MMP-3-induced EMT and genomic instability. Nature, 2005. 436(7047): p. 123-7.

8. Sternlicht, M.D., et al., The Stromal Proteinase MMP3/Stromelysin-1 Promotes Mammary Carcinogenesis. Cell, 1999. 98(2): p. 137-146.

9. Ghajar, C.M., et al., The perivascular niche regulates breast tumour dormancy. Nat Cell Biol, 2013. 15(7): p. 807-17.

10. Farmer, P., et al., A stroma-related gene signature predicts resistance to neoadjuvant chemotherapy in breast cancer. Nat Med, 2009. 15(1): p. 68-74.

11. Weaver, V.M., et al., 64 integrin-dependent formation of polarized three-dimensional architecture confers resistance to apoptosis in normal and malignant mammary epithelium. Cancer Cell, 2002. 2(3): p. 205-216.

12. Nam, J.M., et al., Breast cancer cells in three-dimensional culture display an enhanced radioresponse after coordinate targeting of integrin alpha5beta1 and fibronectin. Cancer Res, 2010. 70(13): p. 5238-48. 
13. Minn, A.J., et al., Genes that mediate breast cancer metastasis to lung. Nature, 2005. 436(7050): p. 518-524.

14. Fournier, M.V., et al., Gene expression signature in organized and growth-arrested mammary acini predicts good outcome in breast cancer. Cancer Res, 2006. 66(14): p. 7095-102.

15. Martin, K.J., et al., Prognostic breast cancer signature identified from 3D culture model accurately predicts clinical outcome across independent datasets. PLoS One, 2008. 3(8): p. e2994.

16. Gudjonsson, T., et al., Normal and tumor-derived myoepithelial cells differ in their ability to interact with luminal breast epithelial cells for polarity and basement membrane deposition. Journal of Cell Science, 2002. 115(1): p. 39-50.

17. Russell, T.D., et al., Myoepithelial Cell Differentiation Markers in Ductal Carcinoma in Situ Progression. The American Journal of Pathology, 2015. 185(11): p. 3076-3089.

18. Wang, X., et al., p63 expression in normal, hyperplastic and malignant breast tissues. Breast Cancer, 2002. 9(3): p. 216-9.

19. Ingthorsson, S., et al., Context-Dependent Function of Myoepithelial Cells in Breast Morphogenesis and Neoplasia. Current Molecular Biology Reports, 2015: p. 1-7.

20. Allinen, M., et al., Molecular characterization of the tumor microenvironment in breast cancer. Cancer Cell, 2004. 6(1): p. 17-32.

21. Fisher, E.R., et al., Conservative management of intraductal carcinoma (DCIS) of the breast. Journal of Surgical Oncology, 1991. 47(3): p. 139-147.

22. Muschler, J., et al., Division of Labor among the $\alpha 684$ Integrin, 61 Integrins, and an E3 Laminin Receptor to Signal Morphogenesis and B-Casein Expression in Mammary Epithelial Cells. Mol Biol Cell, 1999. 10(9): p. 2817-2828.

23. Yurchenco, P., Y. Cheng, and H. Colognato, Laminin forms an independent network in basement membranes. J Cell Biol, 1992. 117(5): p. 1119-1133.

24. Weir, M.L., et al., Dystroglycan loss disrupts polarity and B-casein induction in mammary epithelial cells by perturbing laminin anchoring. Journal of Cell Science, 2006. 119(19): p. 40474058.

25. Pöschl, E., et al., Collagen IV is essential for basement membrane stability but dispensable for initiation of its assembly during early development. Development, 2004. 131(7): p. 1619-1628.

26. Pujuguet, P., et al., Nidogen-1 regulates laminin-1-dependent mammary-specific gene expression. Journal of Cell Science, 2000. 113(Pt 5): p. 849-858.

27. Barcellos-Hoff, M.H., et al., Functional differentiation and alveolar morphogenesis of primary mammary cultures on reconstituted basement membrane. Development, 1989. 105(2): p. 22335.

28. Weaver, V.M., et al., Reversion of the malignant phenotype of human breast cells in threedimensional culture and in vivo by integrin blocking antibodies. J Cell Biol, 1997. 137(1): p. 23145.

29. Colognato, H., D.A. Winkelmann, and P.D. Yurchenco, Laminin Polymerization Induces a Receptor-Cytoskeleton Network. J Cell Biol, 1999. 145(3): p. 619-631.

30. Kim, B.G., et al., Laminin-332-Rich Tumor Microenvironment for Tumor Invasion in the Interface Zone of Breast Cancer. The American Journal of Pathology, 2011. 178(1): p. 373-381.

31. Iyengar, P., et al., Adipocyte-secreted factors synergistically promote mammary tumorigenesis through induction of anti-apoptotic transcriptional programs and proto-oncogene stabilization. Oncogene, 2003. 22(41): p. 6408-6423.

32. Iyengar, P., et al., Adipocyte-derived collagen VI affects early mammary tumor progression in vivo, demonstrating a critical interaction in the tumor/stroma microenvironment. The Journal of clinical investigation, 2005. 115(5): p. 1163-1176. 
33. Chaudhuri, O., et al., Extracellular matrix stiffness and composition jointly regulate the induction of malignant phenotypes in mammary epithelium. Nat Mater, 2014.

34. Alcaraz, J., et al., Laminin and biomimetic extracellular elasticity enhance functional differentiation in mammary epithelia. The EMBO Journal, 2008. 27(21): p. 2829-2838.

35. Paszek, M.J., et al., Tensional homeostasis and the malignant phenotype. Cancer Cell, 2005. 8(3): p. 241-254.

36. Watson, R.J., et al., Ultrastructural observations on the basal lamina in the normal human breast. J Anat, 1988. 156: p. 1-10.

37. Lopez, J.I., et al., In situ force mapping of mammary gland transformation. Integrative biology : quantitative biosciences from nano to macro, 2011. 3(9): p. 910-921.

38. Halfter, W., et al., Protein composition and biomechanical properties of in vivo-derived basement membranes. Cell Adh Migr, 2012. 7(1): p. 64-71.

39. Arendt, L.M., et al., Stroma in Breast Development and Disease. Seminars in cell \& developmental biology, 2010. 21(1): p. 11-18.

40. Ferguson, J.E., et al., Changes in the extracellular matrix of the normal human breast during the menstrual cycle. Cell and Tissue Research, 1992. 268(1): p. 167-177.

41. Ricciardelli, C., et al., Regulation of Stromal Versican Expression by Breast Cancer Cells and Importance to Relapse-free Survival in Patients with Node-negative Primary Breast Cancer. Clinical Cancer Research, 2002. 8(4): p. 1054-1060.

42. Rudnick, J. and C. Kuperwasser, Stromal biomarkers in breast cancer development and progression. Clinical \& Experimental Metastasis, 2012. 29(7): p. 663-672.

43. Zhang, P., et al., Identification of genetic loci that control mammary tumor susceptibility through the host microenvironment. Sci Rep, 2015. 5: p. 8919.

44. Slattery, M.L., et al., Matrix Metalloproteinase Genes Are Associated with Breast Cancer Risk and Survival: The Breast Cancer Health Disparities Study. PLoS ONE, 2013. 8(5): p. e63165.

45. Kelemen, L.E., et al., Genetic variation in stromal proteins decorin and lumican with breast cancer: investigations in two case-control studies. Breast Cancer Res, 2008. 10(6): p. R98.

46. Vargas, A., et al., Gene expression profiling of tumour epithelial and stromal compartments during breast cancer progression. Breast Cancer Research and Treatment, 2012. 135(1): p. 153165.

47. Canavese, G., et al., Expression of proteoglycan versican in in situ breast lesions: Relations between stromal changes, histotype, and invasion. Pathology - Research and Practice, 2011. 207(2): p. 97-103.

48. Oda, G., et al., Significance of stromal decorin expression during the progression of breast cancer. Oncol Rep, 2012. 28(6): p. 2003-8.

49. Freire, J., et al., Collagen, type XI, alpha 1: An accurate marker for differential diagnosis of breast carcinoma invasiveness in core needle biopsies. Pathology - Research and Practice, 2014. 210(12): p. 879-884.

50. Schedin, P., et al., Mammary ECM composition and function are altered by reproductive state. Molecular Carcinogenesis, 2004. 41(4): p. 207-220.

51. Schedin, P., Pregnancy-associated breast cancer and metastasis. Nat Rev Cancer, 2006. 6(4): p. 281-291.

52. Lyons, T.R., et al., Postpartum mammary gland involution drives progression of ductal carcinoma in situ through collagen and COX-2. Nat Med, 2011. 17(9): p. 1109-1115.

53. Provenzano, P.P., et al., Collagen density promotes mammary tumor initiation and progression. BMC Med, 2008. 6: p. 11.

54. Boyd, N.F., et al., Evidence That Breast Tissue Stiffness Is Associated with Risk of Breast Cancer. PLoS ONE, 2014. 9(7): p. e100937. 
55. Plodinec, M., et al., The nanomechanical signature of breast cancer. Nat Nano, 2012. 7(11): p. 757-765.

56. Onitilo, A.A., et al., Breast Cancer Subtypes Based on ER/PR and Her2 Expression: Comparison of Clinicopathologic Features and Survival. Clinical Medicine \& Research, 2009. 7(1-2): p. 4-13.

57. Bloom, H.J.G. and W.W. Richardson, Histological Grading and Prognosis in Breast Cancer: A Study of 1409 Cases of which 359 have been Followed for 15 Years. Br J Cancer, 1957. 11(3): p. 359-377.

58. Tchou, J., et al., Human breast cancer associated fibroblasts exhibit subtype specific gene expression profiles. BMC Medical Genomics, 2012. 5(1): p. 39.

59. Teschendorff, A.E., et al., An immune response gene expression module identifies a good prognosis subtype in estrogen receptor negative breast cancer. Genome Biol, 2007. 8(8): p. R157.

60. Dent, R., et al., Triple-Negative Breast Cancer: Clinical Features and Patterns of Recurrence. Clinical Cancer Research, 2007. 13(15): p. 4429-4434.

61. Bergamaschi, A., et al., Extracellular matrix signature identifies breast cancer subgroups with different clinical outcome. The Journal of Pathology, 2008. 214(3): p. 357-367.

62. Chang, J., et al., Stiffness of tumours measured by shear-wave elastography correlated with subtypes of breast cancer. European Radiology, 2013. 23(9): p. 2450-2458.

63. Azim, H.A., Jr., et al., Association between SPARC mRNA Expression, Prognosis and Response to Neoadjuvant Chemotherapy in Early Breast Cancer: A Pooled <italic>in-silico</italic> Analysis. PLoS ONE, 2013. 8(4): p. e62451.

64. Bae, Y.K., et al., Fibronectin expression in carcinoma cells correlates with tumor aggressiveness and poor clinical outcome in patients with invasive breast cancer. Human Pathology, 2013. 44(10): p. 2028-2037.

65. Weigelt, B., et al., HER2 signaling pathway activation and response of breast cancer cells to HER2-targeting agents is dependent strongly on the 3D microenvironment. Breast Cancer Research and Treatment, 2010. 122(1): p. 35-43.

66. Novaro, V., C.D. Roskelley, and M.J. Bissell, Collagen-IV and laminin-1 regulate estrogen receptor alpha expression and function in mouse mammary epithelial cells. J Cell Sci, 2003. 116(Pt 14): p. 2975-86.

67. Venables, J.P., Aberrant and Alternative Splicing in Cancer. Cancer Res, 2004. 64(21): p. 76477654.

68. Ghigna, C., C. Valacca, and G. Biamonti, Alternative Splicing and Tumor Progression. Current Genomics, 2008. 9(8): p. 556-570.

69. Di Modugno, F., et al., Splicing program of human MENA produces a previously undescribed isoform associated with invasive, mesenchymal-like breast tumors. Proceedings of the National Academy of Sciences of the United States of America, 2012. 109(47): p. 19280-19285.

70. Brown, L.F., et al., Vascular Stroma Formation in Carcinoma in Situ, Invasive Carcinoma, and Metastatic Carcinoma of the Breast. Clinical Cancer Research, 1999. 5(5): p. 1041-1056.

71. Santimaria, M., et al., Immunoscintigraphic Detection of the ED-B Domain of Fibronectin, a Marker of Angiogenesis, in Patients with Cancer. Clinical Cancer Research, 2003. 9(2): p. 571579.

72. Schiefner, A., M. Gebauer, and A. Skerra, Extra-domain B in Oncofetal Fibronectin Structurally Promotes Fibrillar Head-to-tail Dimerization of Extracellular Matrix Protein. Journal of Biological Chemistry, 2012. 287(21): p. 17578-17588.

73. Fukuda, T., et al., Mice Lacking the EDB Segment of Fibronectin Develop Normally but Exhibit Reduced Cell Growth and Fibronectin Matrix Assembly in Vitro. Cancer Research, 2002. 62(19): p. 5603-5610. 
74. Mao, Y. and J.E. Schwarzbauer, Fibronectin fibrillogenesis, a cell-mediated matrix assembly process. Matrix Biology, 2005. 24(6): p. 389-399.

75. Nam, J.-M., et al., Breast Cancer Cells in Three-dimensional Culture Display an Enhanced Radioresponse after Coordinate Targeting of Integrin a581 and Fibronectin. Cancer Res, 2010. 70(13): p. 5238-5248.

76. Adams, M., et al., Changes in Tenascin-C Isoform Expression in Invasive and Preinvasive Breast Disease. Cancer Res, 2002. 62(11): p. 3289-3297.

77. Hancox, R.A., et al., Tumour-associated tenascin-C isoforms promote breast cancer cell invasion and growth by matrix metalloproteinase-dependent and independent mechanisms. Breast Cancer Res, 2009. 11(2): p. R24.

78. Bordeleau, F., et al., Tissue stiffness regulates serine/arginine-rich protein-mediated splicing of the extra domain B-fibronectin isoform in tumors. Proceedings of the National Academy of Sciences, 2015. 112(27): p. 8314-8319.

79. Alisson-Silva, F., et al., Increase of <italic $>0<$ /italic $>$-Glycosylated Oncofetal Fibronectin in High Glucose-Induced Epithelial-Mesenchymal Transition of Cultured Human Epithelial Cells. PLoS ONE, 2013. 8(4): p. e60471.

80. Martin, L. and N. Boyd, Mammographic density. Potential mechanisms of breast cancer risk associated with mammographic density: hypotheses based on epidemiological evidence. Breast Cancer Research, 2008. 10(1): p. 201.

81. Schummer, M., et al., Comparison of Breast Cancer to Healthy Control Tissue Discovers Novel Markers with Potential for Prognosis and Early Detection. PLoS ONE, 2010. 5(2): p. e9122.

82. Lee, S., et al., Differentially Expressed Genes Regulating the Progression of Ductal Carcinoma In Situ to Invasive Breast Cancer. Cancer Research, 2012. 72(17): p. 4574-4586.

83. Maller, O., et al., Collagen architecture in pregnancy-induced protection from breast cancer. Journal of Cell Science, 2013. 126(18): p. 4108-4110.

84. Seo, B.R., et al., Obesity-dependent changes in interstitial ECM mechanics promote breast tumorigenesis. Science Translational Medicine, 2015. 7(301): p. 301ra130-301ra130.

85. Raub, C.B., B.J. Tromberg, and S.C. George, Second-Harmonic Generation Imaging of SelfAssembled Collagen Gels, in Second Harmonic Generation Imaging. 2013, Taylor \& Francis. p. 245-270.

86. Helleman, J., et al., Association of an Extracellular Matrix Gene Cluster with Breast Cancer Prognosis and Endocrine Therapy Response. Clinical Cancer Research, 2008. 14(17): p. 55555564.

87. Ioachim, E., et al., Immunohistochemical expression of extracellular matrix components tenascin, fibronectin, collagen type IV and laminin in breast cancer: their prognostic value and role in tumour invasion and progression. European Journal of Cancer, 2002. 38(18): p. 2362-2370.

88. Janson, I.A. and A.J. Putnam, Extracellular matrix elasticity and topography: Material-based cues that affect cell function via conserved mechanisms. Journal of Biomedical Materials Research Part A, 2015. 103(3): p. 1246-1258.

89. Lang, N.R., et al., Biphasic response of cell invasion to matrix stiffness in three-dimensional biopolymer networks. Acta Biomaterialia, 2015. 13: p. 61-67.

90. Barton, M.B., R. Harris, and S.W. Fletcher, Does this patient have breast cancer?: The screening clinical breast examination: should it be done? how? JAMA, 1999. 282(13): p. 1270-1280.

91. Vinnicombe, S.J., et al., What are the characteristics of breast cancers misclassified as benign by quantitative ultrasound shear wave elastography? European Radiology, 2014. 24(4): p. 921-926.

92. Berg, W.A., et al., Quantitative Maximum Shear-Wave Stiffness of Breast Masses as a Predictor of Histopathologic Severity. American Journal of Roentgenology, 2015. 205(2): p. 448-455. 
93. Falou, O., et al., Evaluation of Neoadjuvant Chemotherapy Response in Women with Locally Advanced Breast Cancer Using Ultrasound Elastography. Translational Oncology, 2013. 6(1): p. 17-24.

94. Brisson, B.K., et al., Type III Collagen Directs Stromal Organization and Limits Metastasis in a Murine Model of Breast Cancer. Am J Pathol, 2015. 185(5): p. 1471-1486.

95. Abba, M.C., et al., Transcriptomic changes in human breast cancer progression as determined by serial analysis of gene expression. Breast Cancer Research, 2004. 6(5): p. R499-R513.

96. Liu, J., et al., TGF-B blockade improves the distribution and efficacy of therapeutics in breast carcinoma by normalizing the tumor stroma. Proceedings of the National Academy of Sciences, 2012. 109(41): p. 16618-16623.

97. Provenzano, P.P., et al., Collagen reorganization at the tumor-stromal interface facilitates local invasion. BMC Med, 2006. 4(1): p. 38.

98. Conklin, M.W., et al., Aligned Collagen Is a Prognostic Signature for Survival in Human Breast Carcinoma. Am J Pathol, 2011. 178(3): p. 1221-1232.

99. Fraley, S.I., et al., Three-dimensional matrix fiber alignment modulates cell migration and MT1MMP utility by spatially and temporally directing protrusions. Scientific Reports, 2015. 5: p. 14580.

100. Kraning-Rush, C.M., et al., Microfabricated collagen tracks facilitate single cell metastatic invasion in 3D. Integrative Biology, 2013. 5(3): p. 606-616.

101. Provenzano, P.P., et al., Contact Guidance Mediated Three-Dimensional Cell Migration is Regulated by Rho/ROCK-Dependent Matrix Reorganization. Biophysical Journal, 2008. 95(11): p. 5374-5384.

102. Wei, S.C., et al., Matrix stiffness drives epithelial-mesenchymal transition and tumour metastasis through a TWIST1-G3BP2 mechanotransduction pathway. Nat Cell Biol, 2015. 17(5): p. 678-88.

103. Baker, A.M., et al., Lysyl oxidase enzymatic function increases stiffness to drive colorectal cancer progression through FAK. Oncogene, 2013. 32(14): p. 1863-1868.

104. Evans, A., et al., Can shear-wave elastography predict response to neoadjuvant chemotherapy in women with invasive breast cancer? British Journal of Cancer, 2013. 109(11): p. 2798-2802.

105. Lee, S., et al., Shear-Wave Elastography for the Detection of Residual Breast Cancer After Neoadjuvant Chemotherapy. Annals of Surgical Oncology, 2015: p. 1-9.

106. Hayashi, M., et al., Evaluation of Tumor Stiffness by Elastography Is Predictive for Pathologic Complete Response to Neoadjuvant Chemotherapy in Patients with Breast Cancer. Annals of Surgical Oncology, 2012. 19(9): p. 3042-3049.

107. Nguyen, T.V., et al., Sorafenib resistance and JNK signaling in carcinoma during extracellular matrix stiffening. Biomaterials, 2014. 35(22): p. 5749-5759.

108. Wang, F., et al., Reciprocal interactions between B1-integrin and epidermal growth factor receptor in three-dimensional basement membrane breast cultures: A different perspective in epithelial biology. Proceedings of the National Academy of Sciences, 1998. 95(25): p. 1482114826.

109. Mocanu, M.-M., et al., Associations of ErbB2, 61-integrin and lipid rafts on Herceptin (Trastuzumab) resistant and sensitive tumor cell lines. Cancer Letters, 2005. 227(2): p. 201-212.

110. Guo, W., et al., 64 Integrin Amplifies ErbB2 Signaling to Promote Mammary Tumorigenesis. Cell, 2006. 126(3): p. 489-502.

111. Balanis, N., et al., beta3 integrin-EGF receptor cross-talk activates p190RhoGAP in mouse mammary gland epithelial cells. Mol Biol Cell, 2011. 22(22): p. 4288-301.

112. Wang, S.E., et al., Transforming Growth Factor 8 Induces Clustering of HER2 and Integrins by Activating Src-Focal Adhesion Kinase and Receptor Association to the Cytoskeleton. Cancer Res, 2009. 69(2): p. 475-482. 
113. Yang, X.H., et al., Disruption of Laminin-Integrin-CD151-Focal Adhesion Kinase Axis Sensitizes Breast Cancer Cells to ErbB2 Antagonists. Cancer Research, 2010. 70(6): p. 2256-2263.

114. Van Keymeulen, A., et al., Reactivation of multipotency by oncogenic PIK3CA induces breast tumour heterogeneity. Nature, 2015. 525(7567): p. 119-23.

115. Koren, S., et al., PIK3CA(H1047R) induces multipotency and multi-lineage mammary tumours. Nature, 2015. 525(7567): p. 114-8.

116. Park, C.C., et al., B(1) Integrin Inhibition Dramatically Enhances Radiotherapy Efficacy in Human Breast Cancer Xenografts. Cancer research, 2008. 68(11): p. 4398-4405.

117. Vandenbroucke, R.E. and C. Libert, Is there new hope for therapeutic matrix metalloproteinase inhibition? Nat Rev Drug Discov, 2014. 13(12): p. 904-927.

118. van 't Veer, L.J., et al., Gene expression profiling predicts clinical outcome of breast cancer. Nature, 2002. 415(6871): p. 530-536.

119. Korkola, J.E., et al., Differentiation of Lobular versus Ductal Breast Carcinomas by Expression Microarray Analysis. Cancer Res, 2003. 63(21): p. 7167-7175.

120. Chang, H.Y., et al., Robustness, scalability, and integration of a wound-response gene expression signature in predicting breast cancer survival. Proceedings of the National Academy of Sciences of the United States of America, 2005. 102(10): p. 3738-3743.

121. Ma, X.J., et al., Gene expression profiling of the tumor microenvironment during breast cancer progression. Breast Cancer Res, 2009. 11(1): p. R7.

122. Jansen, M.P.H.M., et al., Molecular Classification of Tamoxifen-Resistant Breast Carcinomas by Gene Expression Profiling. Journal of Clinical Oncology, 2005. 23(4): p. 732-740.

123. Castellana, B., et al., ASPN and GJB2 Are Implicated in the Mechanisms of Invasion of Ductal Breast Carcinomas. Journal of Cancer, 2012. 3: p. 175-183.

124. Cha, S., et al., In Situ Proteomic Analysis of Human Breast Cancer Epithelial Cells Using Laser Capture Microdissection: Annotation by Protein Set Enrichment Analysis and Gene Ontology. Molecular \& Cellular Proteomics : MCP, 2010. 9(11): p. 2529-2544.

125. Suwiwat, S., et al., Expression of Extracellular Matrix Components Versican, Chondroitin Sulfate, Tenascin, and Hyaluronan, and Their Association with Disease Outcome in Node-Negative Breast Cancer. Clinical Cancer Research, 2004. 10(7): p. 2491-2498.

126. Chia, J., et al., Evidence for a Role of Tumor-Derived Laminin-511 in the Metastatic Progression of Breast Cancer. The American Journal of Pathology, 2007. 170(6): p. 2135-2148.

127. Kwon, S.-Y., et al., Laminin 332 Expression in Breast Carcinoma. Applied immunohistochemistry \& molecular morphology : AIMM / official publication of the Society for Applied Immunohistochemistry, 2012. 20(2): p. 159-164.

128. Zheng, W.Q., L.M. Looi, and P.L. Cheah, A comparison of the patterns of laminin expression in fibroadenoma, fibrocystic diseases, pre-invasive and invasive ductal breast carcinoma. Pathology, 2001. 33(3): p. 303-6.

129. Carpenter, P.M., et al., Laminin 5 expression in metaplastic breast carcinomas. Am J Surg Pathol, 2008. 32(3): p. 345-53.

130. Korah, R., et al., Coordinate loss of fibroblast growth factor 2 and laminin 5 expression during neoplastic progression of mammary duct epithelium. Hum Pathol, 2007. 38(1): p. 154-60.

131. Matsumoto, E.-i., et al., Expression of Fibronectin Isoforms in Human Breast Tissue: Production of Extra Domain A+/Extra Domain B+ by Cancer Cells and Extra Domain A+ by Stromal Cells. Japanese Journal of Cancer Research, 1999. 90(3): p. 320-325.

132. Yao, E.S., et al., Increased beta1 integrin is associated with decreased survival in invasive breast cancer. Cancer Res, 2007. 67(2): p. 659-64.

133. Gilkes, D.M., et al., Collagen Prolyl Hydroxylases Are Essential for Breast Cancer Metastasis. Cancer Res, 2013. 73(11): p. 3285-3296. 
134. Xiong, G., et al. Prolyl-4-hydroxylase $\alpha$ subunit 2 promotes breast cancer progression and metastasis by regulating collagen deposition. BMC cancer, 2014. 14, 1 DOI: 10.1186/1471-240714-1.

135. Xiong, G., et al., Prolyl-4-hydroxylase alpha subunit 2 promotes breast cancer progression and metastasis by regulating collagen deposition. BMC Cancer, 2014. 14: p. 1.

136. Goto, R., et al., Quantitative LC-MS/MS Analysis of Proteins Involved in Metastasis of Breast Cancer. PLoS ONE, 2015. 10(7): p. e0130760.

137. Oskarsson, T., et al., Breast cancer cells produce tenascin C as a metastatic niche component to colonize the lungs. Nat Med, 2011. 17(7): p. 867-874.

138. Guttery, D.S., et al., Association of invasion-promoting tenascin-C additional domains with breast cancers in young women. Breast Cancer Res, 2010. 12(4): p. R57.

139. Lim, G.-H., et al., Syndecan-1 is a potential biomarker for triple-positive breast carcinomas in Asian women with correlation to survival. Singapore Medical Journal, 2014. 55(9): p. 468-472.

140. Nguyen, T.L., et al., Syndecan-1 Overexpression Is Associated With Nonluminal Subtypes and Poor Prognosis in Advanced Breast Cancer. American Journal of Clinical Pathology, 2013. 140(4): p. 468-474.

141. Auvinen, P., et al., Hyaluronan in Peritumoral Stroma and Malignant Cells Associates with Breast Cancer Spreading and Predicts Survival. Am J Pathol, 2000. 156(2): p. 529-536.

142. Auvinen, P., et al., Increased hyaluronan content and stromal cell CD44 associate with HER2 positivity and poor prognosis in human breast cancer. International Journal of Cancer, 2013. 132(3): p. 531-539.

143. Troup, S., et al., Reduced Expression of the Small Leucine-rich Proteoglycans, Lumican, and Decorin Is Associated with Poor Outcome in Node-negative Invasive Breast Cancer. Clinical Cancer Research, 2003. 9(1): p. 207-214.

144. Leygue, E., et al., Lumican and decorin are differentially expressed in human breast carcinoma. J Pathol, 2000. 192(3): p. 313-20.

145. Baba, F., et al., Syndecan-1 and syndecan-4 are overexpressed in an estrogen receptor-negative, highly proliferative breast carcinoma subtype. Breast Cancer Research and Treatment, 2006. 98(1): p. 91-98.

146. Matsuda, K., et al., Glypican-1 Is Overexpressed in Human Breast Cancer and Modulates the Mitogenic Effects of Multiple Heparin-binding Growth Factors in Breast Cancer Cells. Cancer Res, 2001. 61(14): p. 5562-5569.

147. Maxhimer, J.B., et al., Heparanase-1 expression is associated with the metastatic potential of breast cancer. Surgery, 2002. 132(2): p. 326-333.

148. GAWTHORPE, S., et al., Heparanase and COX-2 Expression as Predictors of Lymph Node Metastasis in Large, High-grade Breast Tumors. Anticancer Research, 2014. 34(6): p. 2797-2800.

a. 